\title{
Evaluating Sensitivity of an AAR-Affected Concrete Arch Dam to the Effects of Structural Joints and Solar Radiation
}

\author{
M. Lamea ${ }^{1}$ and H. Mirzabozorg ${ }^{2}$ \\ Department of Civil Engineering, K. N. Toosi University of Technology, Tehran, Iran \\ ${ }^{1}$ m_dena@dena.kntu.ac.ir \\ 2 mirzabozorg@kntu.ac.ir
}

УДК 539.4

\section{Оценка чувствительности бетонной арочной плотины, ослабленной реак- цией щелочей цемента с заполнителями бетона, к виду конструкционных соединений и эффекту солнечной радиации}

\section{М. Ламеа, Г. Мирзабозорг}

Факультет гражданского строительства, Технологический университет им. К. Н. Туси, Тегеран, Иран

Реакция щелочей цеемента с заполнителями бетона может влиять на предельную прочность и конструкционные характеристики смоченных бетонных структур, таких как арочные плотины. Кроме химически зависимых факторов, таких как подверженность щуелочно-силикатным реакииям, влажность, смесь материалов и т.п., существуют и другие, которые усложняют моделирование данного процесса. При этом важное значение имеют следующие структурныле факторы: напряжения, трещины и их распределение, а также температурные распределения в поврежденных структурах. Точность и адекватность моделирования вышеуказанных факторов обеспечивают верификацию расчетных результатов. Напряженное состояние конструкиии определяется в основном параметрами составляющих ее соединений, а температурное распределение - солнечной радиацией. При оценке поведения выпукло-вогнутой бетонной плотины, ослабленной из-за реакции щелочей цемента с заполнителями бетона, учитываются составляющие соединений конструкции и солнечная радиация. Кроме результатов расчетов для конечной стадии получены оченки с учетом истории нагружения плотины. При оченке уровня напряжений оба фактора являются очень важными, однако при оценке уровня допустимых перемещений эффект солнечной радиации оказывается менее критичным. На промежуточных стадиях деформации плотины наблюдается другая тенденция, причем учет в модели нелинейных свойств материалов может привести к качественно иным результатам.

Ключевые слова: реакция щелочей цемента с заполнителями бетона, арочные бетонные плотины, стыковые соединения, метод конечных элементов, эффекты солнечной радиации.

Introduction. Alkali aggregate reaction (AAR) is a chemical phenomenon with significant injuries to the concrete structures. Wet structures, especially those located in hot regions are more impressible to the reaction. AAR injuries originate from expansion of the AAR gel as well as degradation of concrete elasticity modulus and tensile strength. Concrete dams are known to be from the most important structures subjected to AAR. Discovering the reaction in 1940 's, it was found that it is not only dependent on the medium chemical condition but also is affected by the structural and thermal status of the damaged structure. In Fig. 1, dependency of the reaction to temperature and mechanical 
confinement is indicated. Variation of confinement (mainly due to the governing stress distribution) and mean temperature value changes the reaction progression and its subsequent effects. In the present paper, two impressive factors on the performance of the damaged dams are considered:

(i) solar radiation which affects thermal conditions of the dam body;

(ii) contraction joints which impresses structural responses of the damaged dam.

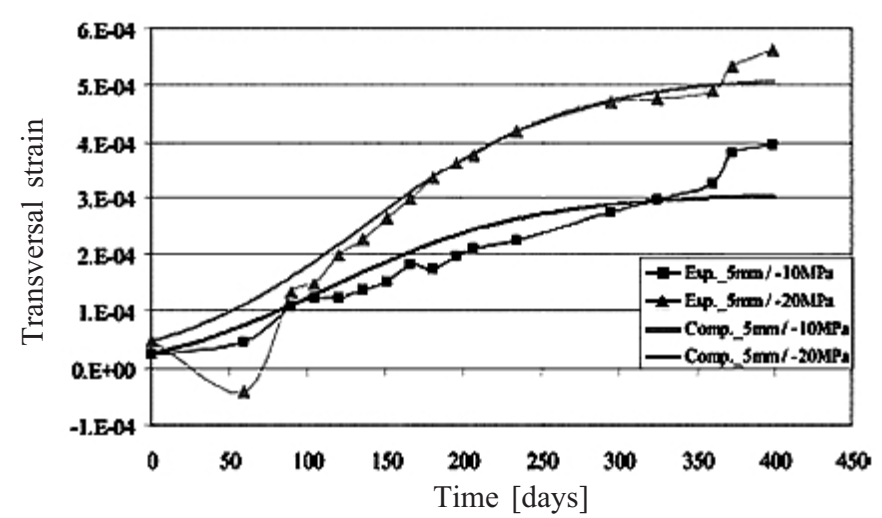

a

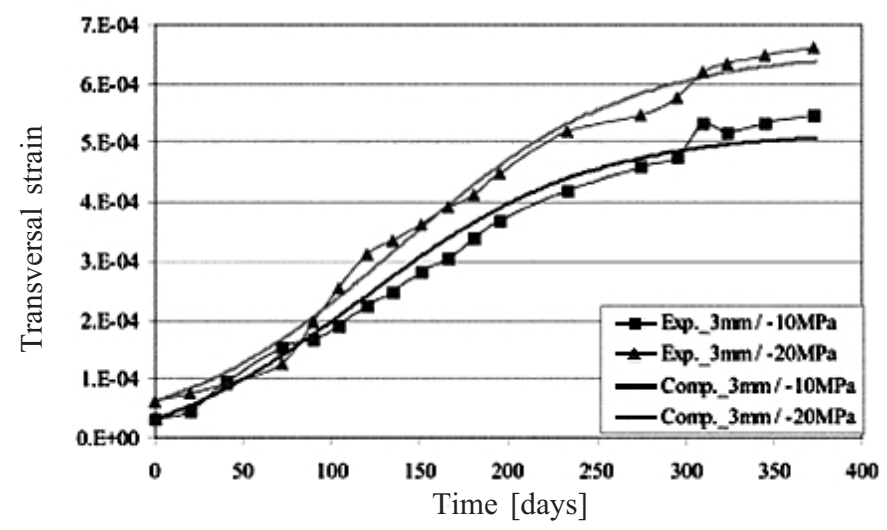

b

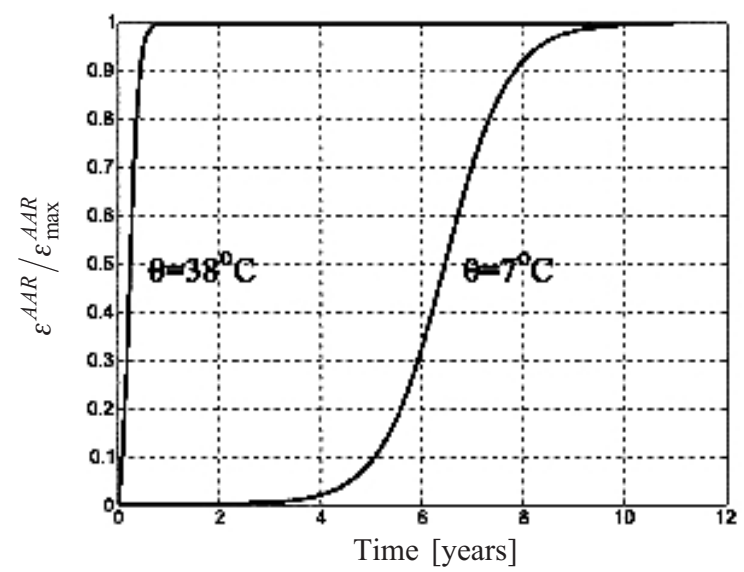

c

Fig. 1. Dependency of AAR effects on mechanical confinement $(a, b)$ ang thermal conditions (c). 
Léger et al. proposed a numerical approach for computing temperature variations in two-dimensional models of concrete gravity dams. They showed that temperature gradient generates tensile stresses at the surface that may lead to cracking. They neglected the effects of solar radiation and deteriorative factors such as AAR [1]. Meyer and Mouvet investigated thermal behavior of a concrete gravity dam in Switzerland utilizing finite element method (FEM). Results showed that air temperature is not singly a good criterion for estimation of internal temperature but solar radiation increases the whole dam temperature up to $4^{\circ} \mathrm{C}$. Moreover, the upstream water can affect temperature variation amplitude [2]. Castellanos and Marin studied the effects of various parameters on thermal behavior of concrete arch and gravity dams using a three-dimensional FE model [3]. Bofang proposed a series of analytical equations for thermal reservoir boundary conditions of concrete dams including deep reservoirs [4]. Malla and Wieland modeled a rather small arch-gravity dam in both linear and nonlinear conditions. In their research, AAR was modeled and in lacking of an accurate simulation, solar radiationwas accounted for by adding corrective values to the temperatures pertinent to downstream face (sunny side). In their research, the volume expansion due to AAR was simulated using equivalent temperature and was taken uniform over the whole dam body [5]. Malla and Wieland analyzed an AAR-damaged dam using ADINA. In the performed nonlinear analysis, AAR-induced inflation was modeled by equal temperature expansion [5]. In the presented research by Curtis, a nonlinear FE-based analysis was performed on a hypothetical dam using GROW 3D (without joints and construction stages). The analysis results showed high importance of modeling stress dependency of the reaction; meanwhile it was indicated that for attaining more reliable results, creep should be modeled in addition to AAR [6]. Parvini et al. investigated seismic behavior of an AAR affected hydraulic structure as a case study. They performed the dynamic analysis after a period of transient static analysis (with consideration of AAR phenomenon), but the effects of solar radiation were not considered during the analysis [7]. Noorzaei et al. analyzed a RCC dam using finite element approach. They implemented the solar radiation effect by adding $1{ }^{\circ} \mathrm{C}$ to ambient environment temperature [8]. Sheibany and Ghaemian developed a detailed three-dimensional FE model of a concrete arch dam immune from AAR. They found that probable cracks occur in very narrow regions of downstream face, which is mainly due to thermal loads [9]. Introducing a new phenomenological model for AAR, Saouma and Perotti developed a numerical computer program for simulating structural effects of AAR. Verifying the model, they simulated an AAR-affected arch-gravity dam, which led to accurate and reliable results. In their research, during the thermal analysis phase, effects of solar radiation were not exactly accounted for [10]. Jin et al. addressed a practical procedure for predicting non-uniform temperature on the solar-exposed faces of arch dams. They found that the temperature distribution on the upstream face depends on the reservoir water condition while the downstream face temperature distribution is mainly influenced by solar radiation. They also showed that this fact leads to forming thermal stresses and crack initiation [11]. Tokmechi studied the probability of crack distribution and cracked zones percentage due to normal alkali silica reaction in a sample RCC dam. He used Monte Carlo method to solve the considered stochastic problem. The results showed that probability of crack distribution dispersion varies from 0.01 to $0.4 \%$ for the considered case [12].

In the current paper, first of all a thermal analysis is performed on the Dez dam considering all of the boundary condition. Solar radiation is also modeled in another separate analysis. Afterwards, a computer program that is previously developed by the authors (for simulating AAR effects) is utilized for modeling the selected case study. Meanwhile, contraction joints are modeled in some of the analyses. Finally, the analyses results are compared for assessing the effects of each of the three components, that is, AAR, solar radiation and contraction joints. 
1. Simulation of Solar Radiation. Sun, the main energy resource of the globe, transmits high values of energy through radiation to every exposed surface. Thermal radiation is in fact a type of emission, so that, every surface hotter than absolute zero emits electromagnetic waves containing significant amounts of energy. Radiation energy may be absorbed by or emitted from surfaces. The total amount of absorbed energy is expressed by [1]:

$$
q_{a}=a I_{t}
$$

Thermal radiation due to temperature difference between the surface and its peripheral environment can be achieved using Stefan-Boltzman law given as [1]:

$$
q_{r}=-e C_{s}\left(T_{a}^{4}-T^{4}\right)
$$

During the current study, wasted heat between surface and air due to radiation is not considered. Finally, Eq. (2) can be rewritten as a pseudo linear relation as following:

$$
q_{r}=-h_{r}\left(T_{a}-T\right)
$$

where $h_{r}$ is defined as

$$
h_{r}=e C_{s}\left(T_{a}^{2}+T^{2}\right)\left(T_{a}+T\right) .
$$

It's worth mentioning that because of especial geometry of double curvature arch dams, they have a high ratio value of area to volume, so it's expected that they be affected by solar radiation emissions. On the other side, because of their curved nature, amount of sun light is different at different points of the dam body. In the current research, variation of surface slope and other effective factors are taken into account and all the parameters used in the provided thermal finite element model was calibrated utilizing the recorded data extracted from the installed instruments within the dam body as referred in [13].

The overall thermal boundary condition of a generic concrete arch dam is depicted in Fig. 2.

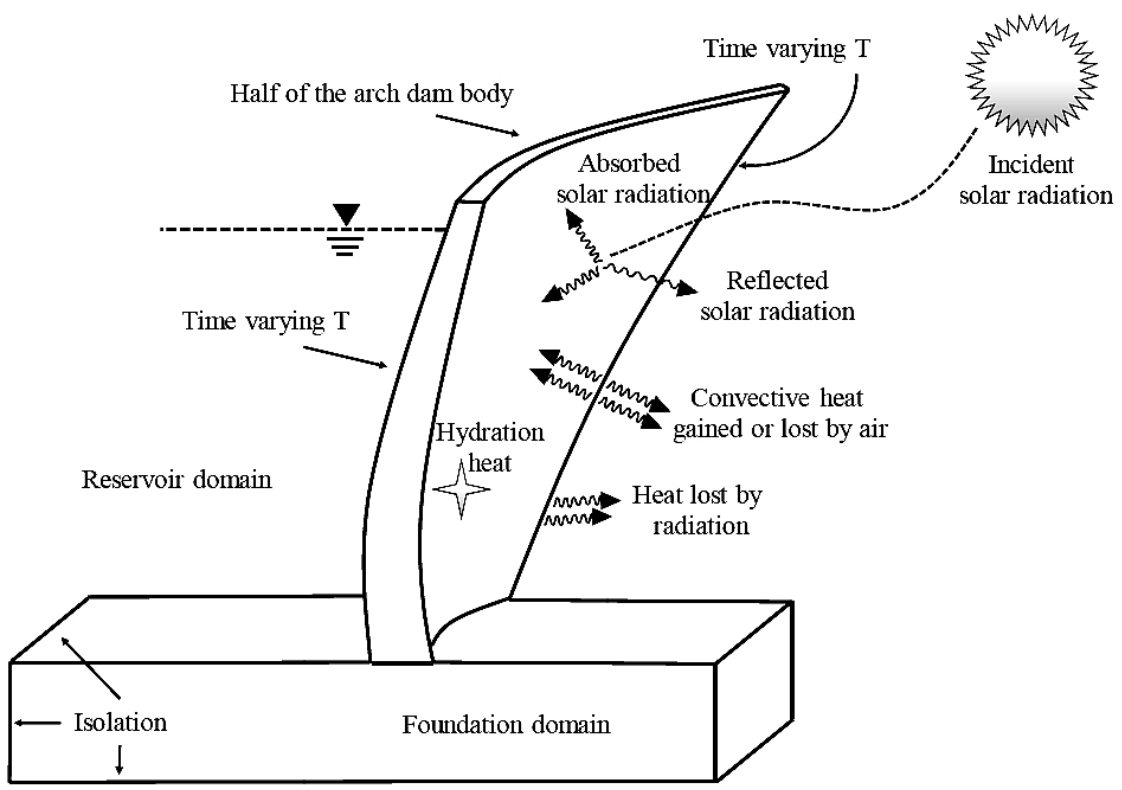

Fig. 2. Heat transfer mechanism for arch dams in 3D space. 
2. Modeling of Structural Joints and Construction Stages. In order to considering effects of contraction joints as well as peripheral joint, they are modeled based on as-built drawings using a kind of 3D node-to-node contact element [14]. Although this kind of elements cannot endure tensile stresses but they tolerates compression in the normal direction and shear forces in the plane tangential direction. When shear force resultant in the joint exceeds the sliding resisting force, the two nodes of the element begin sliding relative to each other. It's worth mentioning that the joint sliding force is calculated using coulomb elastic friction law. Presence of these elements makes a nonlinear condition for the analyses [14]. On the other side, modeling of the dam construction stages are modeled during the nonlinear analyses which would affect the results of analyses. Simulating of construction stages is conducted based on the dam as-built drawings and reports.

3. Mathematical Formulation for Modeling AAR. Several series of mathematical formulations were proposed by researchers for modeling structural effects of alkaliaggregate reaction. Some of these models involve the required perquisites for coordinating with characteristics of concrete dams. Furthermore, some of the models contain the last findings about the reaction and indicate acceptable responses when employed during the structural analyses [15]. The phenomenological model proposed by Saouma and Perotti is one of the robust ones that originates from the governing chemical, physical and mechanical realities about the phenomenon and profits by older presented models, as well $[10,16,17]$. The mathematical formulation of this model is utilized for developing the desired computer program using finite element method. This model assumes that AAR follows with forming a kind of gel which absorbs the medium moisture and expands with the passage of time. Furthermore, the damaged concrete suffering from AAR experiences a degradation in some of the mechanical properties where elasticity modulus and tensile strength are known to be more impressible [17]. This model computes the AAR volumetric expansion rate by the following equation:

$$
\dot{\varepsilon}_{v o l}^{A A R}(t)=\left.\Gamma_{t}\left(f_{t}^{\prime}, \sigma_{1}\right) \Gamma_{c}\left(\bar{\sigma}, f_{c}^{\prime}\right) f(h) \xi(t, \theta) \varepsilon^{\infty}\right|_{\theta=\theta_{0}},
$$

where $\varepsilon^{\infty}$ is the maximum AAR volumetric expansion, $\Gamma_{c}$ and $\Gamma_{t}$ are expansion rate descending factors which insert the effects of absorbing AAR gel by micro- and macrocracks, respectively, and $\xi$ is the reaction kinetics index determined by Eq. (6):

$$
\xi(t, \theta)=\varepsilon^{A A R}(t) / \varepsilon_{\infty}^{A A R}=\frac{1-\exp \left(-\frac{t}{\tau_{c}(\theta)}\right)}{1+\exp \left(-\frac{1-\tau_{l}\left(\theta, I_{\sigma}, f_{c}^{\prime}\right)}{\tau_{c}(\theta)}\right)},
$$

in which $\tau_{c}$ and $\tau_{l}$ point to the characteristic and latency times, respectively. More details about these parameters may be found in [17]. Equation (6) enforces a sigmoid curve to the reaction progression in time.

The computed expansion rate by Eq. (5) may be utilized for determining the volumetric expansion by a simple finite difference method. The computed AAR free volumetric strain is then distributed into corresponding linear values. This is performed in this model through an anisotropic approach which assign the linear strain portion of each direction based on its governing confinement. This is justificatory considering the reaction realities and is performed by three weighting factors pertinent to the three principal directions:

$$
\varepsilon_{i}=W_{i} \varepsilon_{\text {vol }}^{A A R}, \quad i=1,2,3 .
$$


The details of proposed approach for computing $W_{i}$ may be accessible for readers in [17]. Once the linear free strains are computed, the corresponding load vector may be obtained within the provided finite element approach as following:

$$
\left\{\bar{F}_{e / A A R}\right\}=\int_{\Omega}[B]^{T}[D]\left\{\varepsilon^{A A R}\right\} d v,
$$

where $[B]$ is the strain-displacement matrix, $[D]$ is the modulus matrix, and $\left\{\varepsilon^{A A R}\right\}$ is the AAR linear free strains vector.

As mentioned before, AAR may considerably decrease elasticity modulus and tensile strength. The effects is manifested gradually and intensifies up to a limitation for the AAR-affected concrete. In the current study, Eqs. (9) and (10) are utilized for implementing this effect during the analysis [17]:

$$
\begin{gathered}
E(t, \theta)=E_{0}\left[1-\left(1-\beta_{E}\right) \xi(t, \theta)\right], \\
f_{t}(t, \theta)=f_{t, 0}\left[1-\left(1-\beta_{f}\right) \xi(t, \theta)\right],
\end{gathered}
$$

where $E_{0}$ and $f_{t, 0}$ are the primarily elasticity modulus and tensile strength, respectively, $\xi$ is the reaction progression index determined by Eq. (6), and $\beta_{E}$ and $\beta_{f}$ point to the limiting ratios for degradation of elasticity modulus and tensile strength, respectively. It is simply inferred that variation elasticity modulus in time results in direct changes in the material modulus matrix and it make changes to some of the model load vectors [see Eq. (8)] as well as the element and then the total structure stiffness matrix [see Eq. (11) for computing the element stiffness matrix]. Therefore, AAR may be accounted for as a source of nonlinearity for the conducted analyses.

$$
\left[K_{e}\right]=\int_{\Omega}[B]^{T}[D] d v
$$

4. Details of Performed Analyses. After developing the utilized software for implementing AAR and other aforementioned effects, a concrete double-curvature arch dam was selected as case study and analyzed using the provided computer program. The details and results of the analyses are brought in the current section.

4.1. The Case Study Specification. Dez dam is a large thin double-curvature hydroelectric one built in 1963. The dam was constructed on the Dez River in the Northwestern of Khuzestan province, nearby Andimeshk, Iran. It has a reservoir capacity of 3.340 billion cubic meters (Fig. 3).

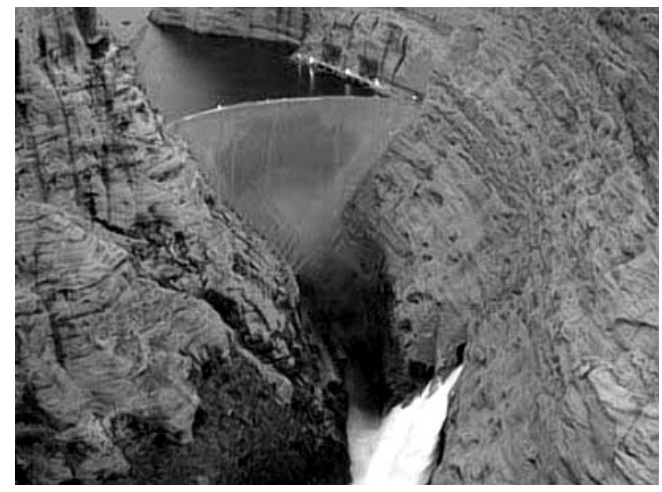

Fig. 3. Downstream view of Dez dam. 
The dam height is $203 \mathrm{~m}$ from the foundation and $190 \mathrm{~m}$ from the riverbed. For the dam crown cantilever, the thicknesses at the crest elevation and base are 4.5 and $21 \mathrm{~m}$, respectively. Crest length is $212 \mathrm{~m}$ and its altitude is 354 masl. The current normal operation level of the reservoir (after optimization) is 352 masl.

The dam body and its Pulvino are modeled using 648 and 144 elements, respectively (Fig. 4a). In addition, reservoir and surrounding foundation rock are meshed to participate in the numerical analyses, so that, the whole of provided model includes 8522 elements as shown in Fig. 4b. The utilized elements for modeling concrete dam, Pulvino (the dam body saddle) and foundation rock are 8 -node brick elements with 8 integration points. Each node has three translational degrees of freedom pertinent to global directions, $x, y$, and $z$. Furthermore, the reservoir is modeled using 8-node fluid brick elements. It should be noted that pressure is the only active degree of freedom of fluid element's nodes (Fig. 4c).

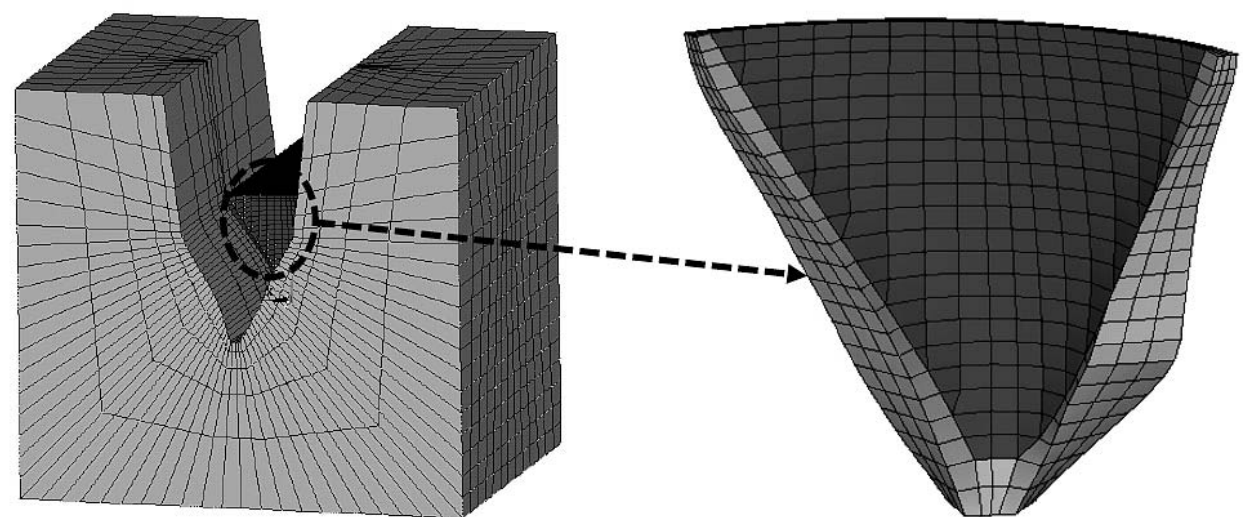

a

$\mathrm{b}$
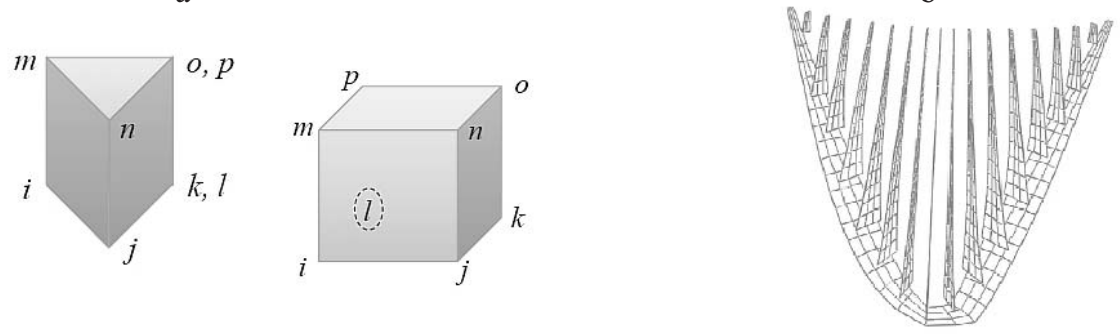

C

d

Fig. 4. Finite element model of dam for thermal analysis (a); FE mesh of the overall model (b); cubed and prism solid-thermal elements (c); peripheral and contraction joints (d).

Elasticity modulus, Poison's ratio, density, and thermal expansion coefficient for the dam body concrete are assumed to be $40 \mathrm{GPa}, 0.2,2400 \mathrm{~N} / \mathrm{m}^{3}$, and $6 \cdot 10^{-6}{ }^{\circ} \mathrm{C}^{-1}$, respectively. The modulus of deformations in saturated and unsaturated parts of the foundation medium are taken as 13 and $15 \mathrm{GPa}$, respectively. All the above-mentioned mechanical parameters were extracted from a comprehensive calibration procedure conducted on the provided model in [18].

4.2. Analyses Results. Using the created FE model and the provided parameters as described above, several analyses are arranged for considering effects of AAR, solar radiation and joints on the performance of the selected double curvature arch dam.

Prior to the desired structural analyses, two transient thermal analyses are performed, one of them with and another without implementing solar radiation effect. Results of the thermal analyses, i.e., nodal temperatures, are arranged as several input files pertinent to all 
desired time steps. Based on the attained results, solar radiation changes distribution of nodal temperatures, especially over the downstream surface. The curved geometry of arch dams creates heat concentration at some areas. Because Dez dam is located in northern hemisphere and considering that the axis of the dam has a slight angle (about $6^{\circ}$ ) to the geographic south, the sun glows to the downstream face and makes heat concentration near the abutments at middle elevations. On the other side, the effect of direct solar radiation is almost negligible on the upstream face because it is not the dam sunny side.

Crest midpoint displacement is one of the sensible structural reactions of concrete arch dams which is commonly monitored using the instruments installed over the dam body. In Figs. 5 and 6, histories of crest displacements at the dam crown cantilever are presented.

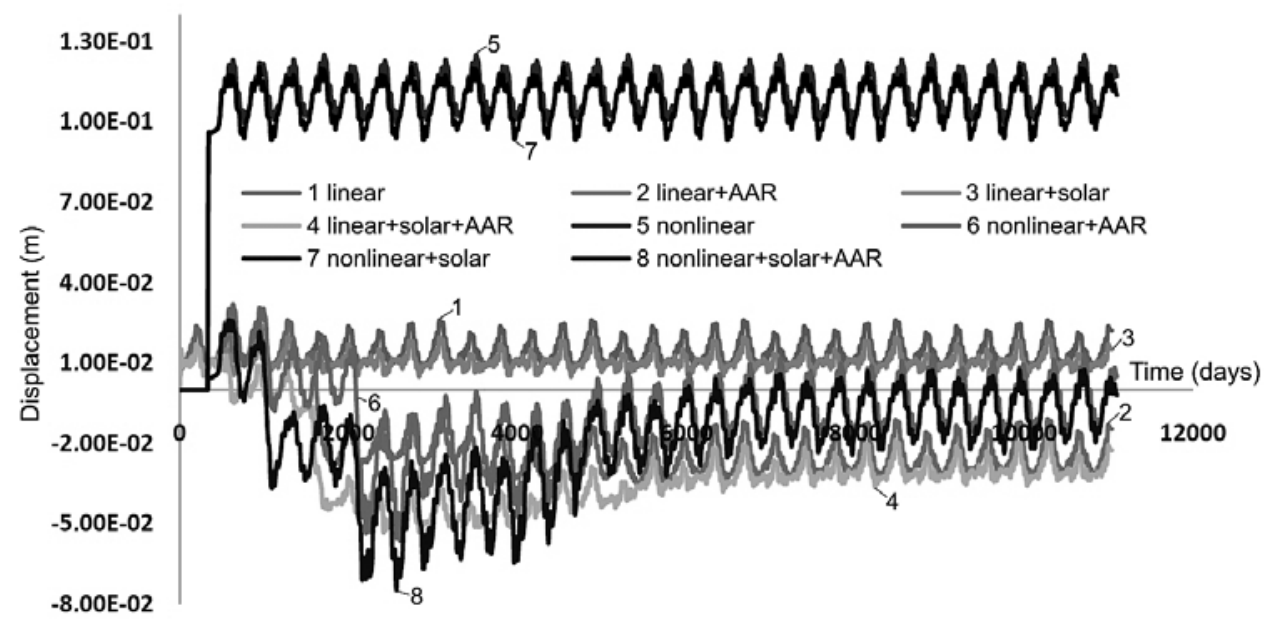

Fig. 5. History of crest horizontal displacements for all performed analyses.

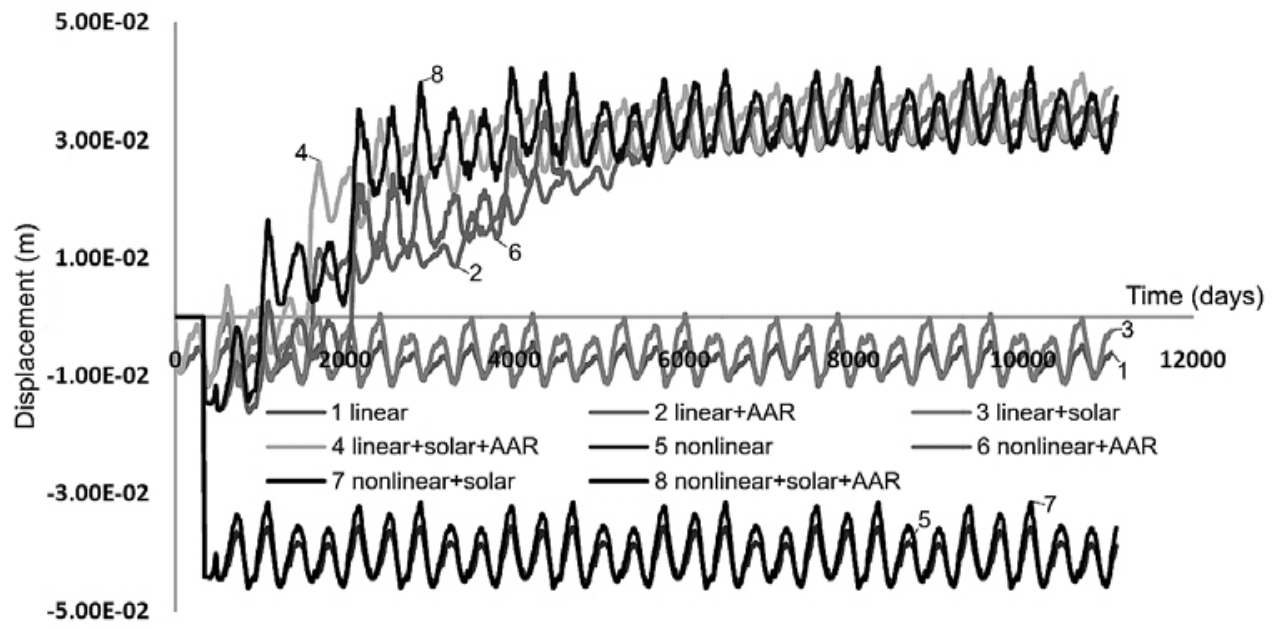

Fig. 6. History of crest vertical displacements for all performed analyses.

Based on what is observed, the second half of the diagrams depicted in Fig. 5 indicates that solar radiation does not significantly affect crest displacements in US/DS direction. On the other side, joints tend to move crest toward downstream; these effects is mitigated when AAR damages the dam body. Furthermore, AAR causes some deviation of 
the crest toward upstream; this is more distinguished when contraction joints are present in the conducted analysis.

Figure 6 again emphasizes on the aforementioned effect of solar radiation on the crest displacement. Although in both Figs. 5 and 6, solar radiation effect in not ignorable in the almost first half of the history duration pertinent to AAR-affected cases. In contrary to horizontal displacements (Fig. 5), in all of the AAR-affected cases, vertical displacements are not considerably affected by modeling of none of solar radiation or contraction joints.

Stress is very important index for structural designers or for other engineers when identifying the probable damages of the structures. Clearly, the zones with high tensile stresses are susceptible for initiation and propagation of macrocracks; furthermore, high compressive stresses may be suitable for crushing or forming of microcracks. In Figs. 7-10, contours of principal stresses pertinent to the last time step of the analyses are presented. The abbreviations used in the figures are as:

Linear analysis with AAR, called as "L+A."

Linear analysis with AAR, including solar radiation effects, called as " $\mathrm{L}+\mathrm{A}+\mathrm{S}$."

Nonlinear analysis (with joints) with AAR, called as "NL+A."

Nonlinear analysis (with joints) with AAR, including solar radiation effects, called as "NL+A+S."

A summary about maximum values of aforementioned figures are presented in Table 1 .

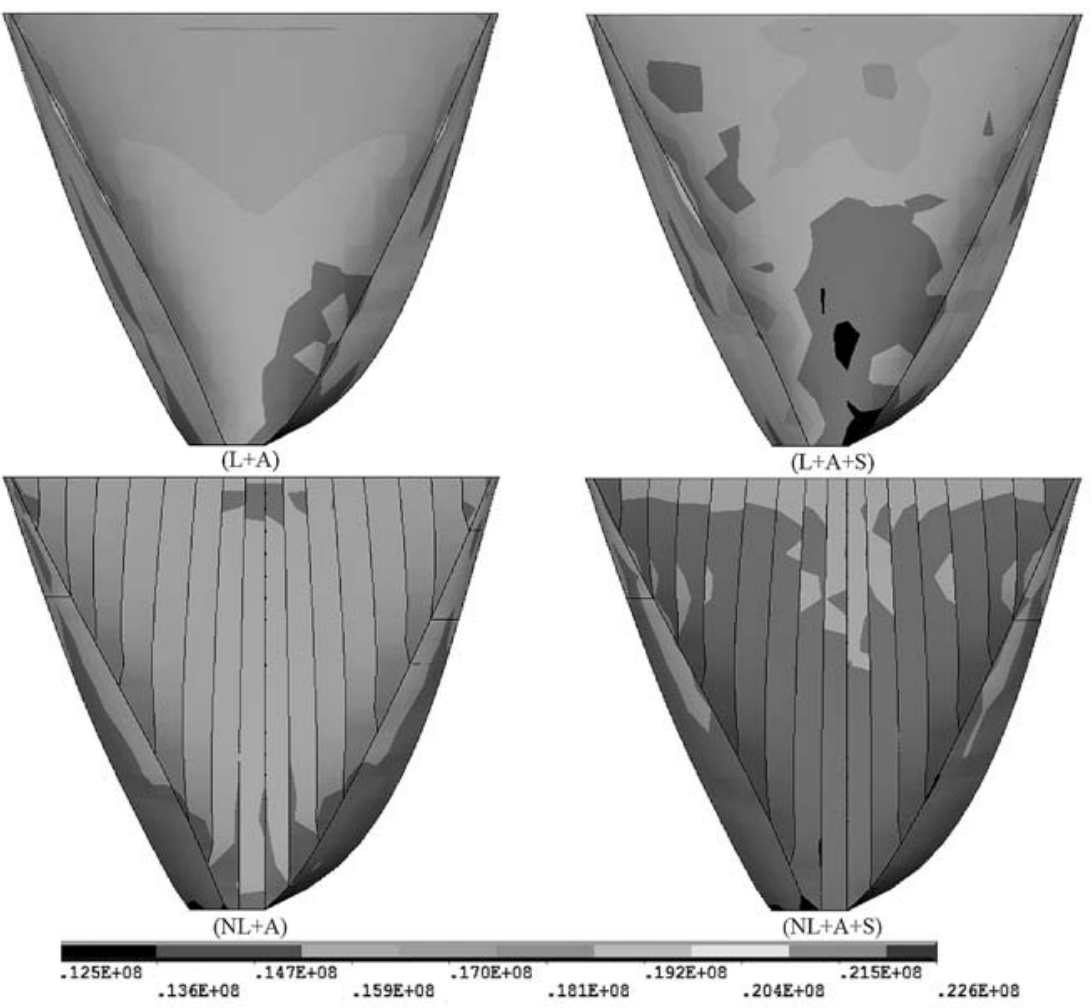

Fig. 7. Contours of 1 st principal stresses on downstream face for the conducted analyses.

The above contours show that joints, as expected, may affect the stress distribution within the dam body, especially, they mitigate the value of maximum tensile stress (max of 1 st principal stress) in the corresponding analyses. On the other side, solar radiation may increase the maximum and minimum of principal stresses in both tensile and compressive aspects. 
$\mathrm{T}$ a b 1 e 1

Maximum and Minimum Values of Principal Stresses (for the Last Time Step)

\begin{tabular}{||c|c|c|c|c||}
\hline \multirow{2}{*}{ Analyses } & \multicolumn{2}{|c|}{ 1st principal stresses (MPa) } & \multicolumn{2}{c||}{ 3rd principal stresses (MPa) } \\
\cline { 2 - 5 } & $\max$ & $\min$ & $\max$ & $\min$ \\
\hline $\mathrm{L}+\mathrm{A}$ & 22.90 & 13.30 & 14.40 & 2.14 \\
$\mathrm{~L}+\mathrm{A}+\mathrm{S}$ & 21.70 & 12.70 & 14.80 & 1.18 \\
$\mathrm{NL}+\mathrm{A}$ & 18.00 & 13.20 & 14.00 & 3.46 \\
$\mathrm{NL}+\mathrm{A}+\mathrm{S}$ & 16.70 & 12.50 & 14.90 & 1.71 \\
\hline $\mathrm{L}+\mathrm{A} / \mathrm{L}+\mathrm{A}+\mathrm{S}$ & 1.06 & 1.05 & 0.97 & 1.81 \\
$\mathrm{NL}+\mathrm{A} / \mathrm{NL}+\mathrm{A}+\mathrm{S}$ & 1.08 & 1.06 & 0.94 & 2.02 \\
$\mathrm{~L}+\mathrm{A} / \mathrm{NL}+\mathrm{A}$ & 1.27 & 1.01 & 1.03 & 0.69 \\
$\mathrm{~L}+\mathrm{A}+\mathrm{S} / \mathrm{NL}+\mathrm{A}+\mathrm{S}$ & 1.30 & 1.02 & 0.90 & 0.69 \\
\hline
\end{tabular}

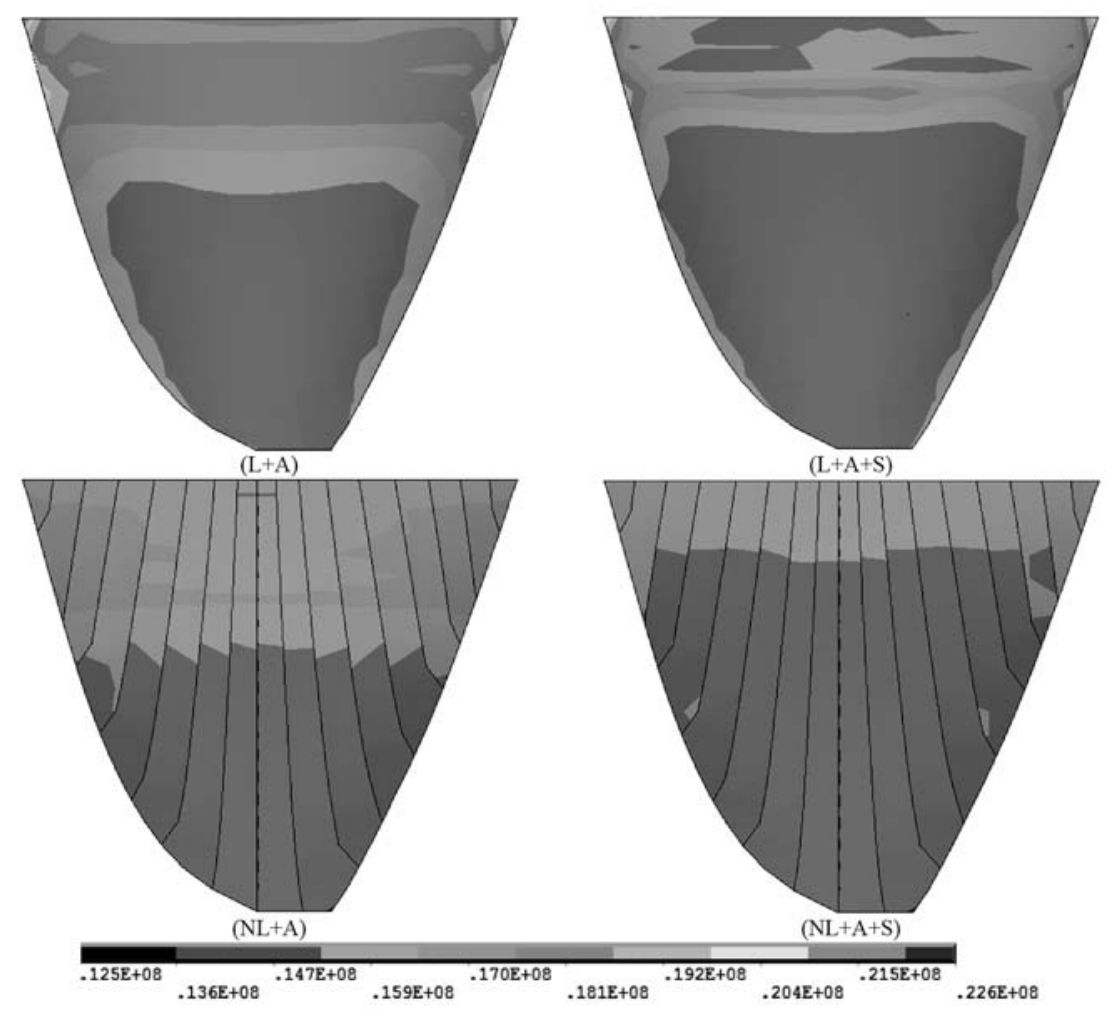

Fig. 8. Contours of 1st principal stresses on up-stream face for the conducted analyses.

In the lower block of Table 1 the ratio of the mentioned extreme values are compared. Considering this part, it may be inferred that the most impressibility is witnessed about maximum of 1 st principal stresses (corresponding to maximum of tensile stresses) and minimum of 3rd principal stresses (corresponding to maximum of compressive stress for the cases including compression). Meanwhile, solar radiation effects on changing all extreme values are small comparing with minimum of 3 rd principal stress. In fact, solar radiation may severely decrease the maximum of compressive stresses. On the other side, simulating structural joint during the analyses may decrease tensile stresses while increase compressive stresses, i.e., it prevails compression during the analyses. 


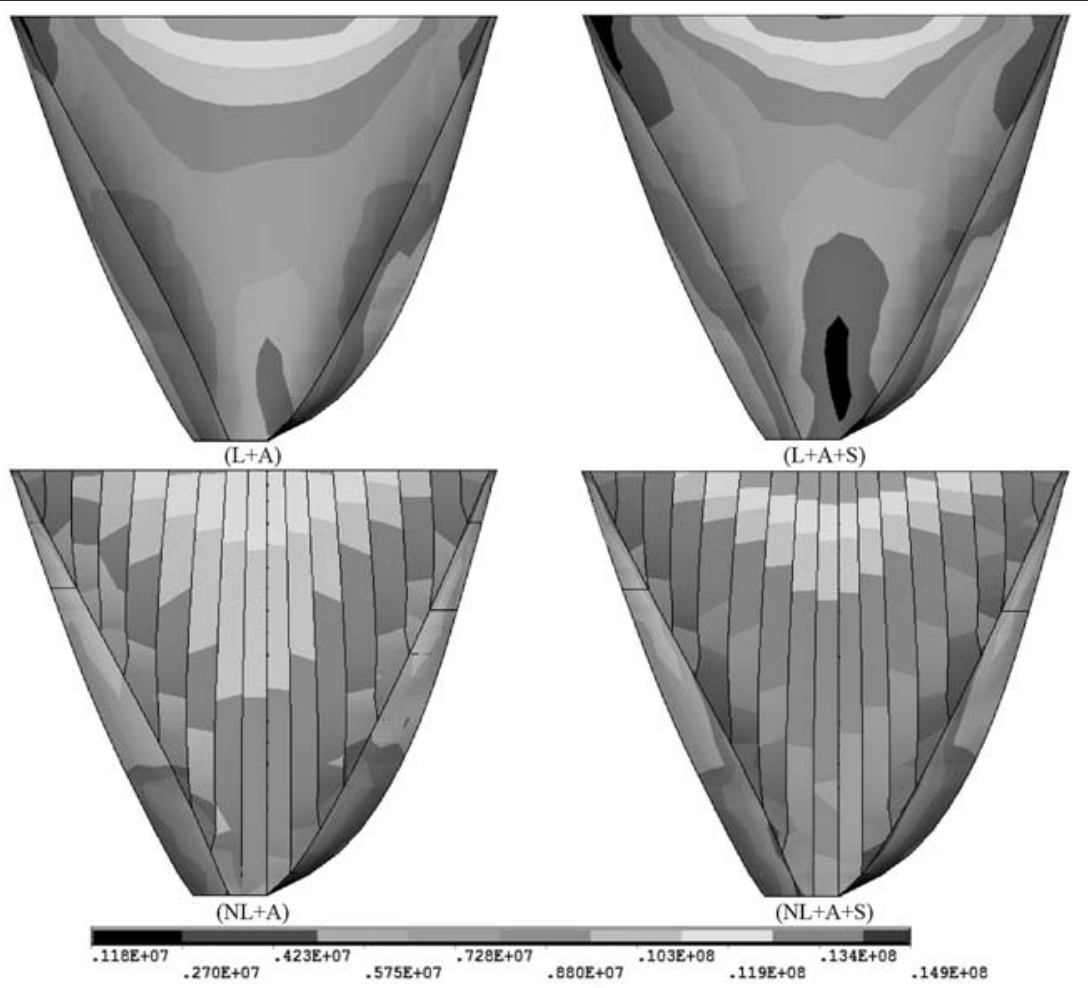

Fig. 9. Contours of 3rd principal stresses on downstream face for the conducted analyses.

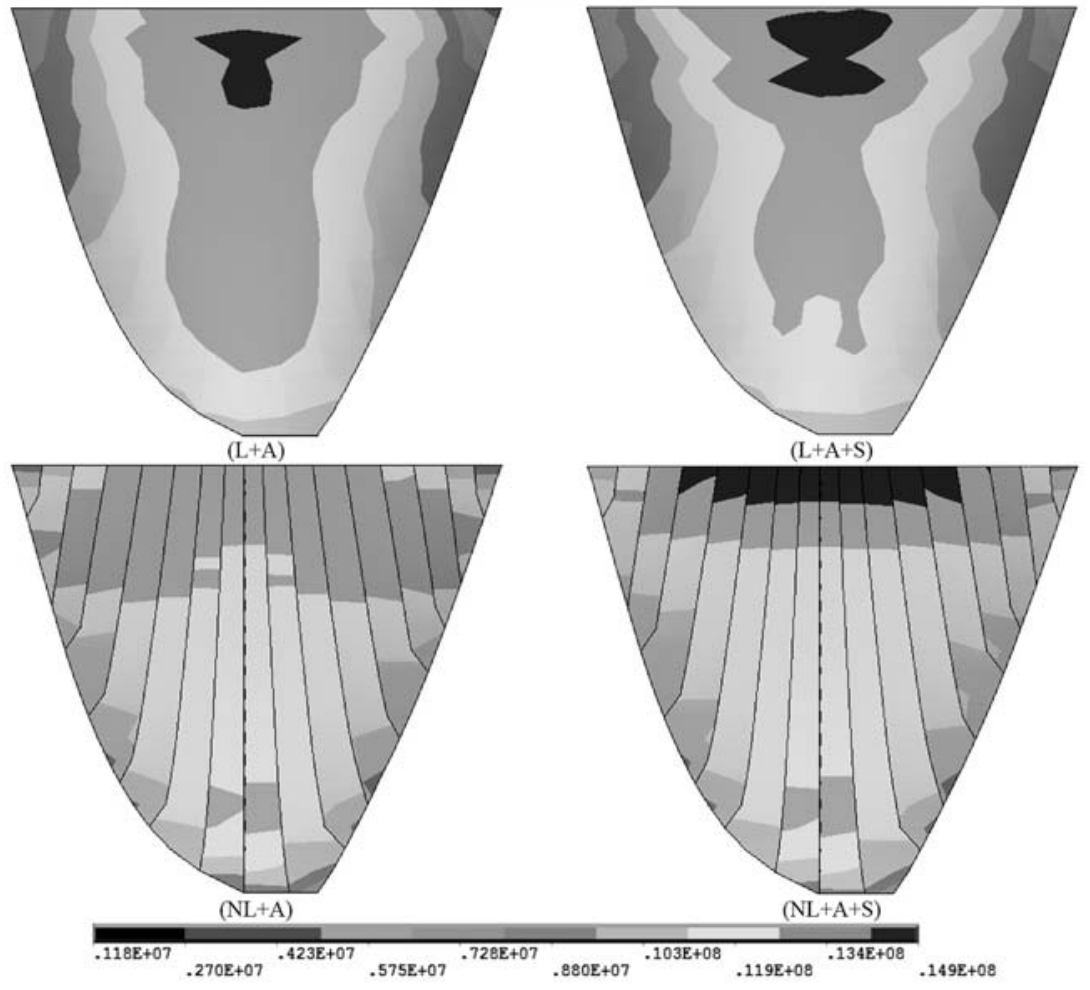

Fig. 10. Contours of 3rd principal stresses on up-stream face for the conducted analyses. 
Along with the above contours which describe the last analyses step results (corresponding to the middle of 30th year), to have a more comprehensive judgment, similar contours pertinent to a middle time step are also presented. Considering Figs. 5 and 6 , during the first half of the analyses period (especially before the time of 2500 days) the differences of diagrams are more highlighted, therefore, the time step of 1800 is selected and the relevant stress contours are presented in Figs. 11-14.

Table 2 and Figs. 11-14 indicate that impressibility of the principal stresses would be intensified more when one selects a middle time step for evaluating the responses instead of considering only the last time step. It's worth noting that the results of earlier steps may affect the subsequent analyses results. This is clearly more influential when material nonlinearity, for example due to formation of crack profiles, is included in the provided models. However this claim needs to be approved through future extensions of current research.

T a b 1 e 2

Maximum and Minimum Values of Principal Stresses (Related to Time of 1800 Days)

\begin{tabular}{|l|c|c|c|c||}
\hline \multirow{2}{*}{ Analyses } & \multicolumn{2}{c|}{ 1st principal stresses $(\mathrm{MPa})$} & \multicolumn{2}{c|}{ 3rd principal stresses $(\mathrm{MPa})$} \\
\cline { 2 - 5 } & $\max$ & $\min$ & $\max$ & $\min$ \\
\hline $\mathrm{L}+\mathrm{A}$ & 16.60 & -1.590 & 6.88 & -12.70 \\
$\mathrm{~L}+\mathrm{A}+\mathrm{S}$ & 18.20 & -0.045 & 12.40 & -8.09 \\
$\mathrm{NL}+\mathrm{A}$ & 7.99 & -1.920 & 3.98 & -6.49 \\
$\mathrm{NL}+\mathrm{A}+\mathrm{S}$ & 14.60 & -1.800 & 10.60 & -8.62 \\
\hline $\mathrm{L}+\mathrm{A} / \mathrm{L}+\mathrm{A}+\mathrm{S}$ & 0.91 & 35.330 & 0.55 & 1.56 \\
$\mathrm{NL}+\mathrm{A} / \mathrm{NL}+\mathrm{A}+\mathrm{S}$ & 0.54 & 1.060 & 0.37 & 0.75 \\
$\mathrm{~L}+\mathrm{A} / \mathrm{NL}+\mathrm{A}$ & 2.07 & 0.830 & 1.73 & 1.96 \\
$\mathrm{~L}+\mathrm{A}+\mathrm{S} / \mathrm{NL}+\mathrm{A}+\mathrm{S}$ & 1.24 & 0.030 & 1.17 & 0.94 \\
\hline
\end{tabular}

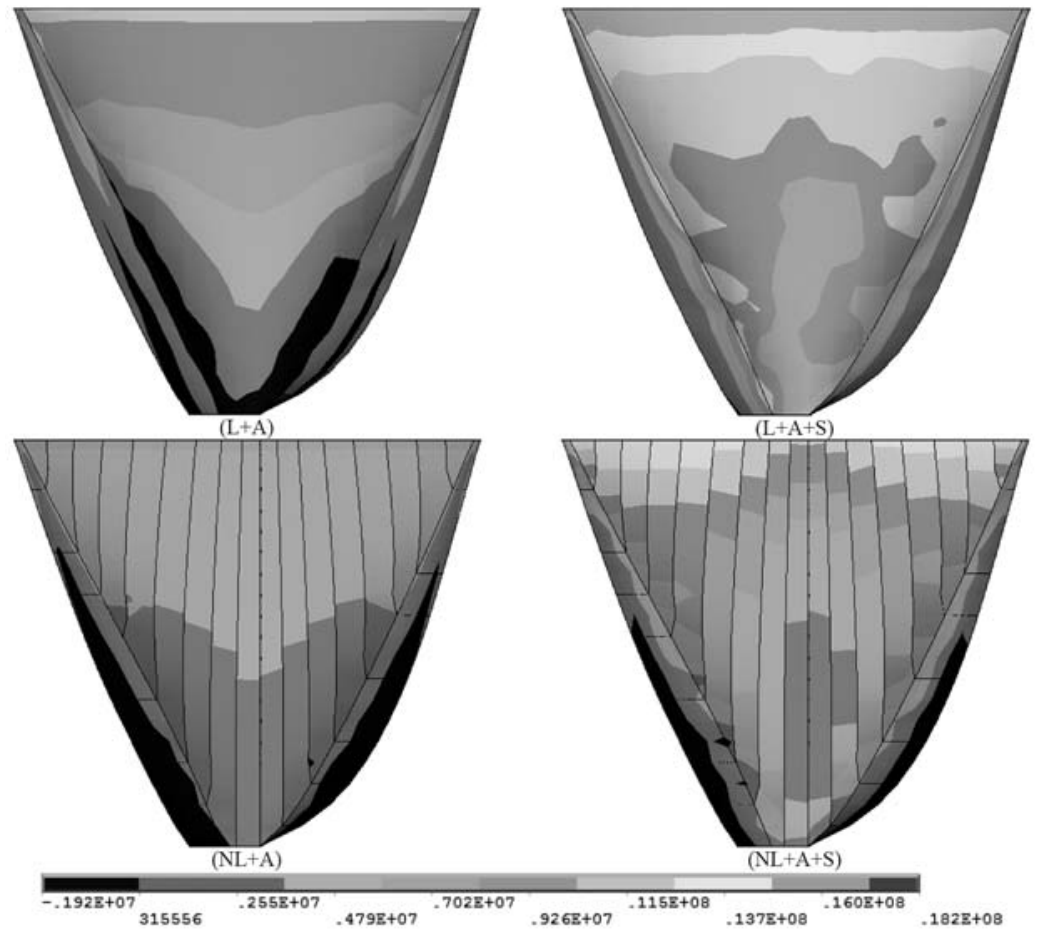

Fig. 11. Contours of 1st principal stresses on downstream face for the time of 1800 days. 


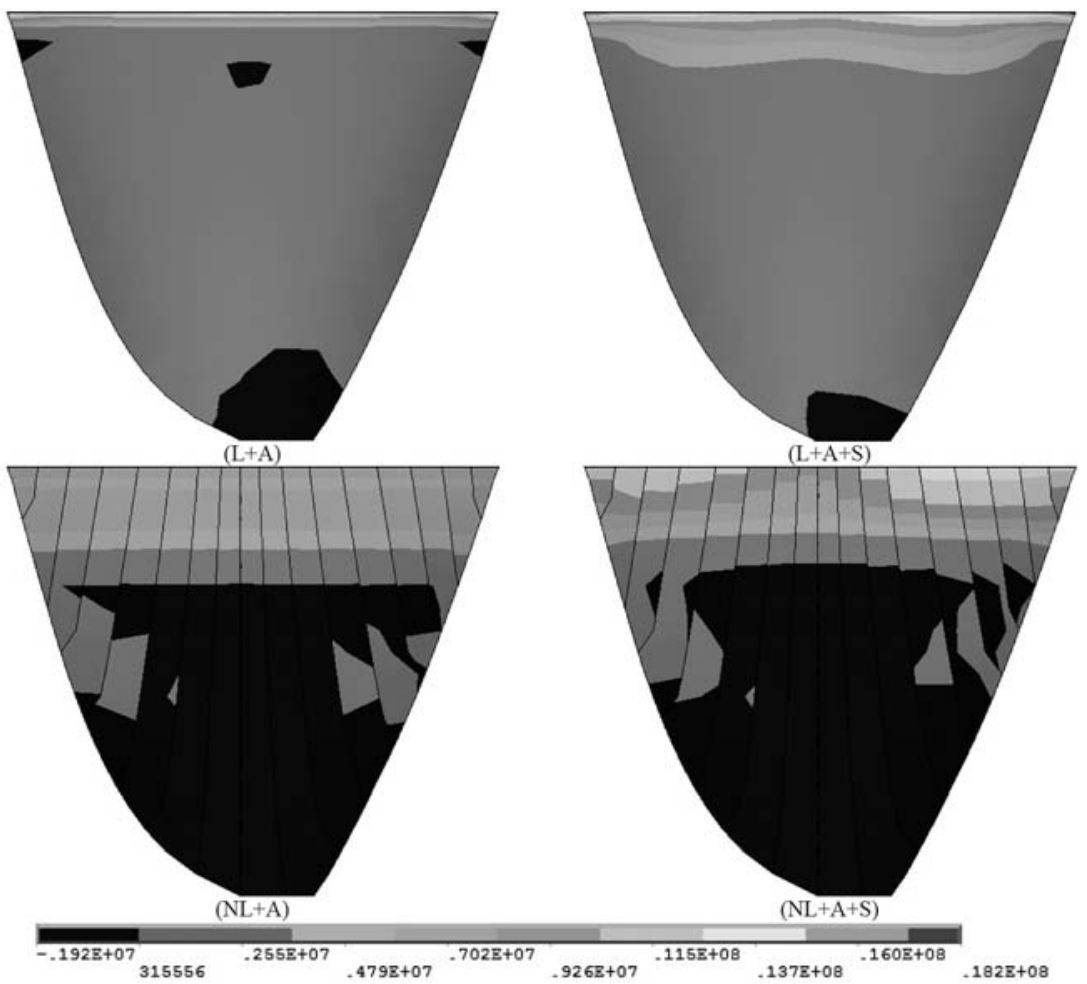

Fig. 12. Contours of 1st principal stresses on upstream face for the time of 1800 days.

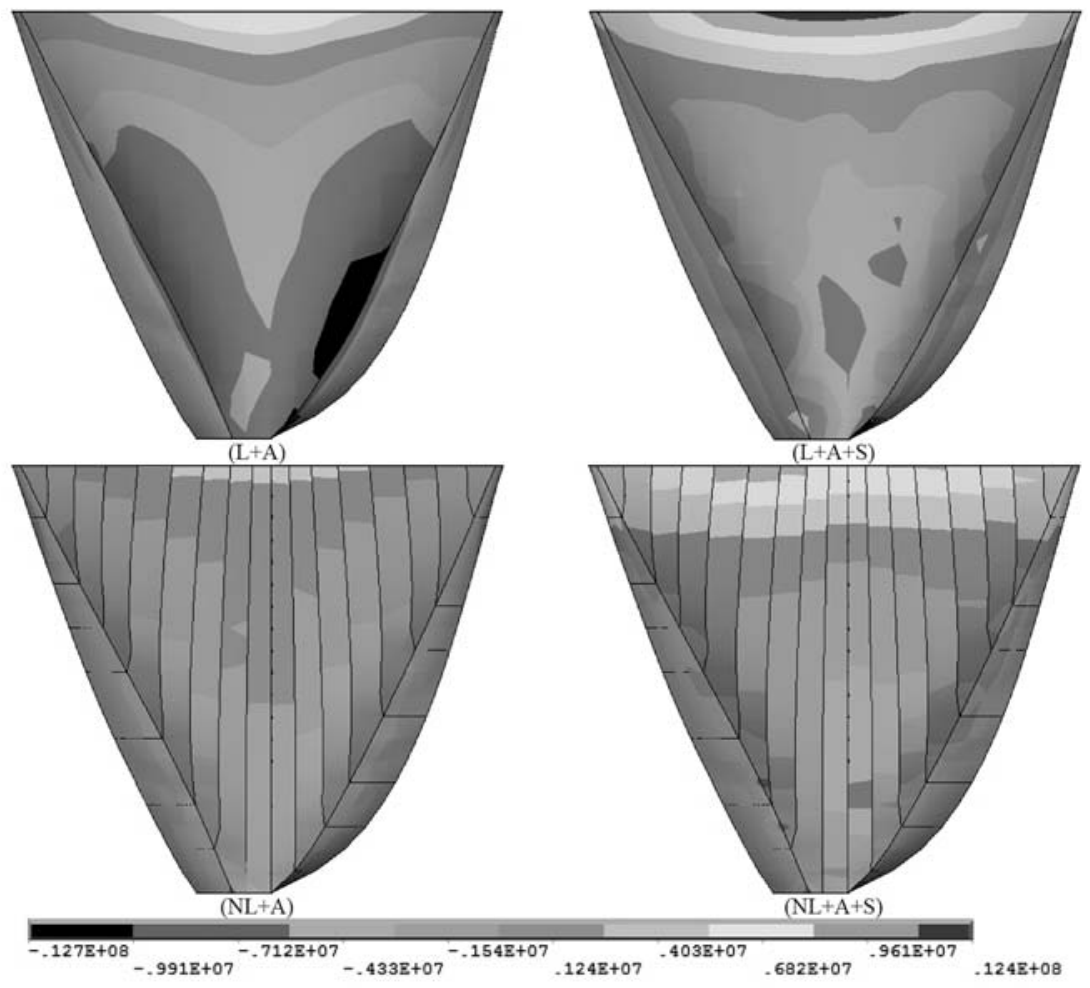

Fig. 13. Contours of 3rd principal stresses on downstream face for the time of 1800 days. 


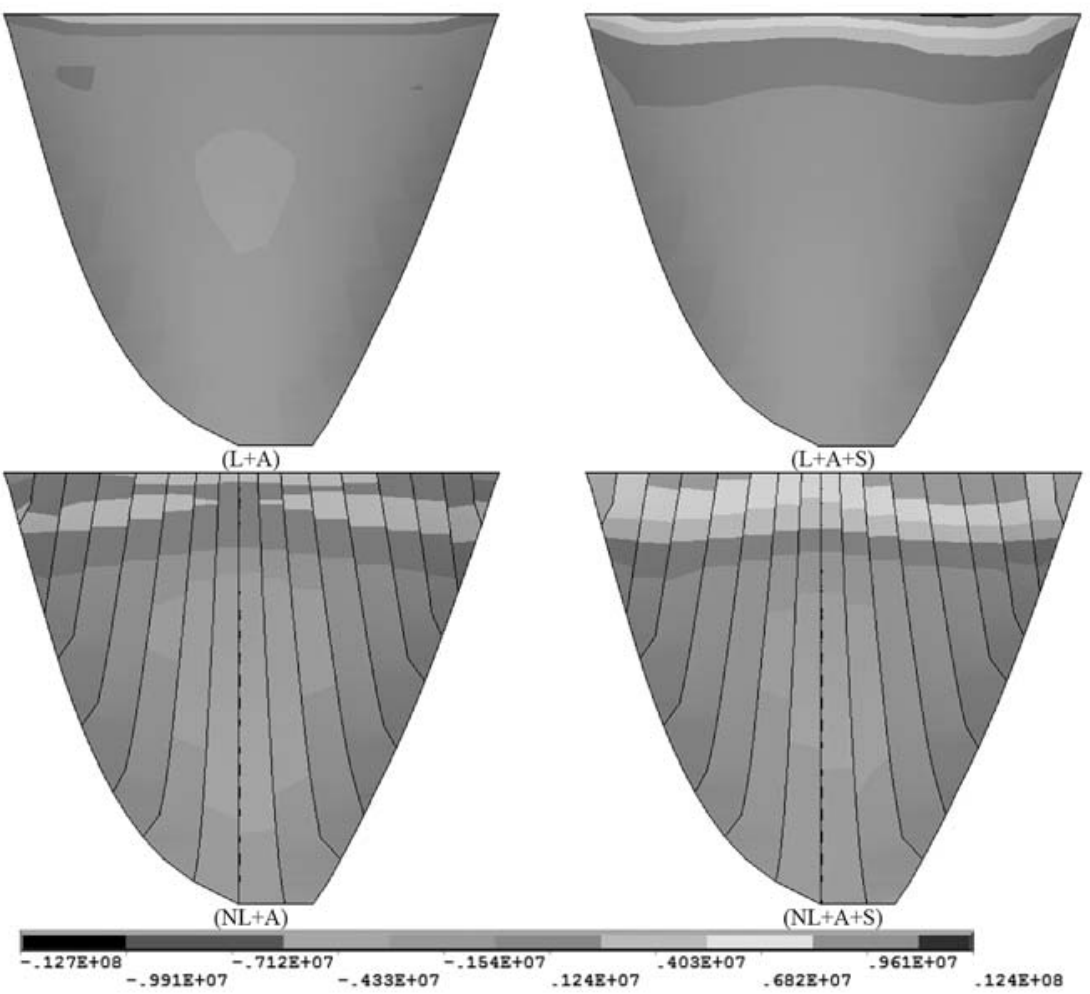

Fig. 14. Contours of 3rd principal stresses on upstream face for the time of 1800 days.

To assess the sensitivity of the analyses results to the aforementioned factors (solar radiation and structural joints), a summary of the principal stress extreme values are presented in Table 2.

4.3. Discussion. In the current research, the main objective is considering the effects of AAR and solar radiation phenomena on the structural behavior of a thin high arch dam developing a rigorous finite element based software. Contraction and peripheral joints effects are simultaneously evaluated during the study procedure. The advantage of the conducted analyses is that AAR, solar radiation and joints effects are considered together for the first time. In fact, the main features modeled and considered in the current study are as following:

(i) modeling contraction and peripheral joints as reported in as-built drawings;

(ii) modeling the effect of solar radiation and obtaining thermal distribution within the dam body using a transient thermal analysis;

(iii) using the thermal and structural properties extracted from a comprehensive calibration study;

(iv) modeling stage construction phenomena including joint grouting processes based on the available constructional reports;

(v) considering the effects of both AAR and solar radiation phenomena on the structural performance of the selected thin high arch dam.

As can be observed, almost all the affecting features were modeled in the conducted analyses. However, a big shortcoming in the current research is modeling the mass concrete as a linear elastic material. As found, the tensile stresses resulted from some of analyses (those including AAR) are beyond the tensile strength commonly expected for mass concrete. 
Conclusions. It may be concluded from the current study that both of the solar radiation and contraction joints have significant effects on simulation of the AAR-affected arch dam. When results of the last analyses steps are compared, it's inferred that solar radiation has no considerable effect on displacement pattern of the crest, although its effect on stress values of the dam is not ignorable yet (especially when minimum of 3rd principal stresses are considered). If results of the analyses in a time step at the first half of the analyses period are considered another judgment may be inferred. During the aforementioned period, when AAR advances toward its extreme level, solar radiation has more sensible effect even on the displacement values. This is more important when material behavior assumed nonlinear. In such cases, responses in earlier steps may approach the history trends toward different values at the last steps. However, this is not accounted for in the current research (where material behavior is assumed linear elastic) and may be followed during the future studies. On the other side, contraction joints impress performance of the considered arch dam in most of the studied conditions. Finally, it is felt that more case studies need to be simulated and considered using the developed program for attaining a more comprehensive judgment.

\section{Резюме}

Реакція лугу цементу із заповнювачами бетону може впливати на граничну міцність $\mathrm{i}$ конструкційні характеристики змочених бетонних структур, таких як аркові греблі. Окрім хімічно залежних чинників, таких як схильність до лужно-силікатних реакцій, вологість, суміш матеріалів і т.П., існують й інші, що ускладнює моделювання даного процесу. При цьому важливе значення мають наступні структурні чинники: напруга, тріщини й їх розподіл, а також температурний розподіл у пошкоджених структурах. Точність і адекватність моделювання цих чинників забезпечує верифікацію розрахункових даних. Напружений стан конструкції визначається в основному параметрами складових іiі з'єднань, а температурний розподіл - сонячною радіацією. При оцінці поведінки опукло-вгнутої бетонної греблі, що ослаблена через реакцію лугу цементу із заповнювачами бетону, враховуються складові з'єднань конструкції і сонячна радіація. Окрім результатів розрахунку для кінцевої стадії отримано оцінки з урахуванням історії навантаження греблі. При оцінці рівня напружень ці чинники $\epsilon$ важливими, однак при оцінці рівня припустимих переміщень ефект сонячної радіації $\epsilon$ менш критичним. На проміжних стадіях деформації греблі має місце інша тенденція, причому врахування в моделі нелінійних властивостей матеріалів може привести до якісно інших результатів.

1. P. Léger, J. Venturelli, and S. S. Bhattacharjee, "Seasonal temperature and stress distributions in concrete gravity dams. Part 1: modelling," Canadian J. Civil Eng., 20, No. 6, 999-1017 (1993).

2. T. Meyer and L. Mouvet, "Behaviour analysis of the Vieux-Emosson arch gravity dam under thermal loads," Dam Eng., 6, 275-292 (1995).

3. J. L. Castellanos and E. M. Marin, "Stress and movements in arch-gravity dams due to thermal action of the environment," Dam Eng., 7 (1996).

4. Zhu Bofang, "Prediction of water temperature in deep reservoirs," Dam Eng., 8, No. 1, 13-26 (1997).

5. S. Malla and M. Wieland, "Analysis of an arch-gravity dam with a horizontal crack," Comput. Struct., 72, No. 1-3, 267-278 (1999).

6. D. D. Curtis, "A review and analysis of AAR-effects in arch dams," in: Proc. of the 11 th Int. Conf. on Alkali-Aggregate Reaction (ICAAR), Quebec, Canada (2000). 
7. M. Parvini, S. Pietruszczak, and V. Gocevski, "Seismic analysis of hydraulic structures affected by alkali-aggregate reaction: a case study," Canadian J. Civil Eng., 28, No. 2, 332-338 (2001).

8. J. Noorzaei, K. H. Bayagoob, W. A. Thanoon, and M. S. Jaafar, "Thermal and stress analysis of Kinta RCC dam," Eng. Struct., 28, No. 13, 1795-1802 (2006).

9. F. Sheibany and M. Ghaemian, "Effects of environmental action on thermal stress analysis of Karaj concrete arch dam," J. Eng. Mech., 132, No. 5, 532-544 (2006).

10. V. Saouma, L. Perotti, and T. Shimpo, "Stress analysis of concrete structures subjected to alkali-aggregate reactions," ACI Struct. J., 104, No. 5, 532-541 (2007).

11. F. Jin, Z. Chen, J. Wang, and J. Yang, "Practical procedure for predicting non-uniform temperature on the exposed face of arch dams," Appl. Therm. Eng., 30, No. 14-15, 2146-2156 (2010).

12. Z. Tokmechi, "The probability of RCC Dams cracking due to NASR," Aust. J. Basic Appl. Sci., 5, No. 5, 768-775 (2011).

13. H. Mirzabozorg, M. A. Hariri-Ardebili, M. Shirkhan, and S. M. Seyed-Kolbadi, "Mathematical modeling and numerical analysis of thermal distribution in arch dams considering solar radiation effect," The Scientific World Journal, 2014 (2014), Article ID 597393, $15 \mathrm{p}$.

14. H. Mirzabozorg, M. Ghaemian, and M.-A. Hariri-Ardebili, "Pulvino and peripheral joint effects on static and seismic safety of concrete arch dams," Scientia Iranica, 20, No. 6, 1579-1594 (2013).

15. V. Saouma and Y. Xi, Literature Review of Alkali Aggregate Reactions in Concrete Dams, Technical Report No. 1 submitted to Swiss Federal Office for Water and Geology, Bienne Switzerland (2004).

16. V. Saouma and L. Perotti, "Alkali aggregate reactions in dams; stress analysis and long term predictions," in: ASDSO Dam Safety Conference, New Orleans (2005).

17. V. Saouma and L. Perotti, "Constitutive model for alkali-aggregate reactions," $A C I$ Mater. J., 103, No. 3, 194-202 (2006).

18. M. Hariri-Ardebili and H. Mirzabozorg, "Feasibility study of Dez arch dam heightening based on nonlinear numerical analysis of existing dam," Arch. Civil Eng., 59, No. 1, 21-49 (2013). 